\title{
Oblique lip-alveolar banding in patients with cleft lip and palate
}

\author{
Sharan Naidoo ${ }^{*}$,a \\ Kurt-W Bütow ${ }^{\text {a,b }}$ \\ ${ }^{a}$ Facial Cleft Deformity Clinic, Department of Maxillofacial and Oral Surgery, University of Pretoria \\ ${ }^{\text {b } C o l l e g e ~ o f ~ H e a l t h ~ S c i e n c e s, ~ U n i v e r s i t y ~ o f ~ K w a Z u l u-N a t a l, ~ S o u t h ~ A f r i c a . ~}$
}

*Corresponding author: Dr Sharan Naidoo, Tel: +27 12319 2232, Mobile: +27 83785 1976,

Telefax: +27 86274 8883, E-mail address: sharannaidoo@gmail.com

\section{Abstract}

We report an oblique lip-alveolar band, a rare banding of soft tissue that involves the lip and alveolus, which we have found in five patientswith cleft lip and palate $(0.2 \%)$, compared with an incidence of the Simonartz lip-lip band of 5.7\%). To our knowledge this has not beenreported previously. In two patients the bands affected the cleft lip and alveolus bilaterally, with or without the palatal cleft, and in three thebands were unilateral cleft lip and alveolus with or without the palatal cleft.

Keywords: Lip-alveolar band; Simonartz' band, cleft lip and palate 


\section{Introduction}

The Simonartz' band is a band of soft tissue that bridges the medial and lateral aspect of the cleft lip. ${ }^{1}$ Semb and Shaw describes it as a soft tissue connection between the medial and lateral margins of the cleft lip, nostril or between the divided alveolar process. There is often disparity between an incomplete cleft, which is fused to the nasal floor, and a Simonartz' band, which is a loose soft tissue bridge between the lips. ${ }^{2}$

\section{Incidence}

In 3942 recorded patients referred to the cleft lip and palate clinic, 2051 (52.0\%) presented with a cleft lip and alveolus, or palate, or both. Five of these $(0.24 \%)$ were recorded as having a lip-to-alveolus band, two of whom had bilateral cleft lip alveolus (Fig. 1) with unilateral lip-alveolar banding, and three of whom had unilateral cleft lip and cleft alveolus cases (Fig2.). In comparison, the incidence of the lip-to-lip (Simonartz') band was $6.0 \%(n=$ 123 ) and of the alveolus-to-alveolus band $0.24 \%(n=5)$.

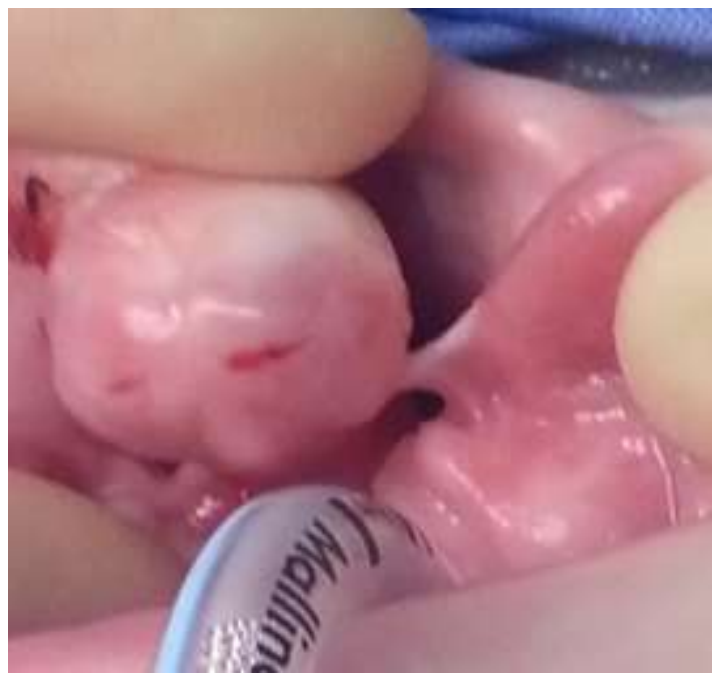

Figure1. Bilateral cleft lip, alveolus and palate with unilateral band (left) 


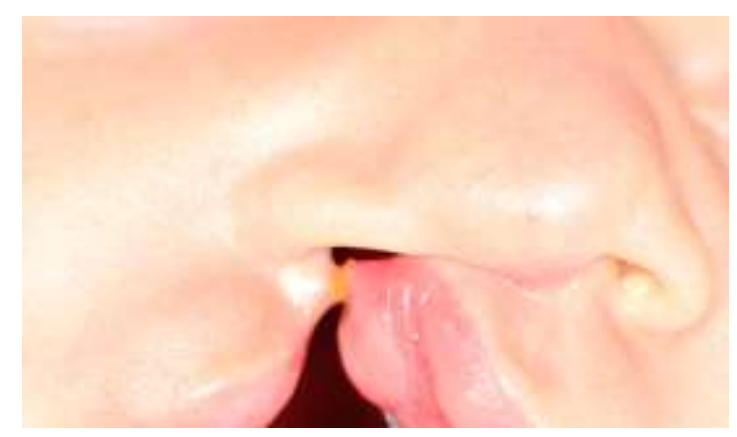

Figure 2. Unilateral lip alveolar cleft (right).

\section{Discussion}

The history behind the Simonartz' band is scant nd we couldfind only a few published papers. The first to refer to it was Dr Gustav Simon (1823-1876), a German surgeon who was renowned for his skill in the management of urogenital fistulas. ${ }^{3}$

The embryology and development of the face is wellunderstood. ${ }^{3,4}$ Despite this, the mechanism of the formationof a Simonartz band remains unknown. There are, however,a number of proposed pathogenetic mechanisms. According to Semb and Shaw the most plausible explanation is a synchronous cellular proliferation between the medial and lateral nasal processes, inadequate approximation of these processes, or impaired apoptosis of the cells within the epithe-lial surfaces. ${ }^{2}$

Veau ${ }^{5,6}$ and Veau and Politzer ${ }^{7}$ postulated that the cause of a soft tissue bridge was due to inadequate mesodermal penetration into the epithelial wall that seperates the maxillary and frontonasal processes, followed by incomplete rupturing of the walls. Maurer suggested that the band resulted from partial healing of the cleft after breakdown. ${ }^{8}$ Töndury implicated the failure of development of the epithelial wall as the cause of formation of the 
band, which was based on the examination of a $64 \mathrm{~mm}$ foetus with a bilateral cleft lip and a unilateral band. ${ }^{9}$

According to Sulik the band originates from a supplementary growth centre within the maxillary process, and this was identified on scanning electron micrographs of a mouse embryo. ${ }^{4}$ The area, which is known as the maxillary prime, is a distinct area that fuses independently of the rest of the facial structure, which results in formation of a band even if there is non-fusion between the frontonasal and maxillary processes. ${ }^{4}$ The presence of banding may result in reduced segmental displacement of the lip alveolar complex, which would translate into more favourable morphology with a reduction in the extent of the surgical procedure. ${ }^{2}$

A different type of banding, which involves the medial and lateral alveolar components, has been described. ${ }^{10}$ This paper introduces another variation of lip banding, as a third type (Fig. 3), which goes from the lip to the alveolar component, as a lip-to-alveolus band. Like the previously-described bands, this new oblique lip-alveolar band also presents as a soft tissue mucosal bridge, which limits lateral displacement of the attached lip component. This

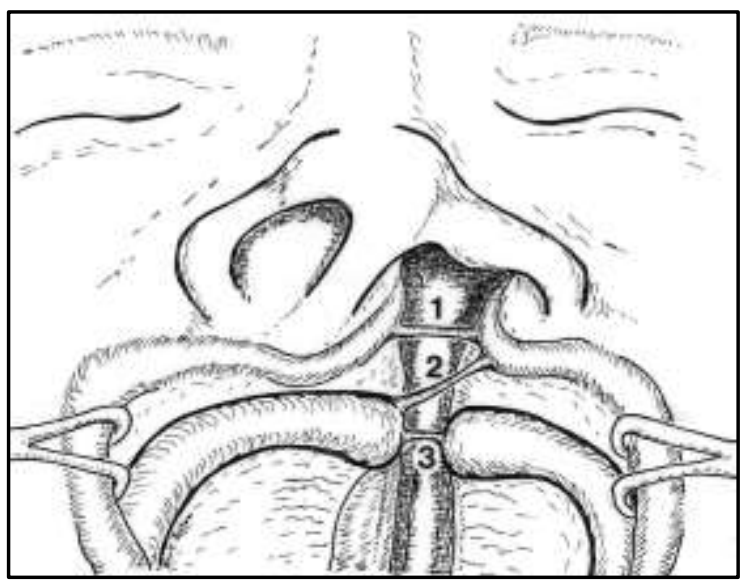

Figure 3. Drawing to present the three different types of banding: 1. lip-to-lip (Simonartz), 2. lip-to-alveolus, 3. alveolus-to-alveolus. 
variation of mucosal soft tissue band, with variations in involved structures, places a greater challenge for adopting suitable developmental theory.

\section{References}

1. Mulliken JB, Schmidt A-G. Gustav Simon's band and the evolution of labial adhesion. J Craniofac Surg 2013;24(1): 108-114.

2. Semb G, Shaw WC. Simonarts' band and facial growth in unilateral clefts of the lip and palate. Cleft Palate Craniofac J 1991;28(1): 40-48.

3. Yatabe MS, Garib DG, Poletto RS. Is the presence of Simonart's band in patients with complete unilateral cleft lip and palate associated with the prevalence of missing maxillary lateral incisors? Am J Orthod Dentofacial Orthop 2013;144:649-653.

4. Sulik KK. Orofacial embryogenesis: a framework for understanding clefting sites. In: Fonseca RJ, Marciani RD, Turvey TA, editors. Oral and maxillofacial surgery, Volume 3. Philadelphia: Saunders; 2009. p.711.

5. Veau V. Le sequelette du bec-de-lièvre. Ann Anat Norm Med Chir 1934;11:873-904.

6. Veau V. Bec-de lièvre: Hypothèses sur la malformation initial edu bec-de lièvre. Ann Anat Pathol Anat Norm Med Chir 1935;12:389-424.

7. Veau V, Politzer G. Embryologie du bec-de-lièvre. Le palais primaire (Formation. Anomalies). Ann Anat Pathol Norm Med Chir 1936;13:275-326.

8. Maurer H. Die Entstehung der Lippen-Kiefer-Spalten bei einem Keimlig von $22 \mathrm{~mm}$. SSL. Z Anat Entwicklungsgesch 1936;105:359-379. 
9. Tönduray G. On the mechanism of cleft formation. In: Pruzansky S, ed. Congenital Anomalies of the Face and Associated Structures. 'proceedings of an International Symposium. Springfield, IL: Charles C. Thomas, 1961:85-101.

10. Engelbrecht H, Bütow K-W. Alveolar band in patients with cleft lip and cleft alveolar deformities. J Craniofac Surg 2013; 24(2):e153. 